\title{
Phycological flora of the Guadalquivir River Basin. Its value in determining the ecoregionalization of the basin
}

\author{
María A. Casco ${ }^{1,2, *}$, Isabel Reyes ${ }^{3}$, Gonzalo Martín ${ }^{3}$, María R. Fernández ${ }^{3}$, Silvia E. Sala ${ }^{1}$ and \\ Julia Toja ${ }^{3}$ \\ ${ }^{1}$ División Ficología, Facultad de Ciencias Naturales y Museo, Universidad Nacional de La Plata, Argentina. \\ 2 Consejo Nacional de Investigaciones Científicas y Técnicas (CONICET). \\ ${ }^{3}$ Departamento de Biología Vegetal y Ecología, Facultad de Biología, Universidad de Sevilla, España. \\ * Corresponding author: casco@fcnym.unlp.edu.ar
}

Received: 19/05/16 Accepted: 13/04/18

\begin{abstract}
Phycological flora of the Guadalquivir River Basin. Its value in determining the ecoregionalization of the basin

In compliance with the Water Framework Directive of the European Union, we needed to diagnose the ecologic quality of the different sections of the rivers of the Guadalquivir basin. In order to establish a regional classification of the water bodies by a grouping into areas of similar characteristics, we took into consideration the benthic phycologic flora of the Guadalquivir-River basin. Benthic algae, being one of the groups of organisms that best define the water quality of rivers, are useful for characterizing the basin's ecoregionalization. We collected multihabitat samples in 109 georeferenced reaches and identified 777 algal taxa: 397 Bacillariophyceae (diatoms), 181 Chlorophyta, 148 Cyanoprokariota, 41 Euglenophyta, 4 Chrysophyceae, 3 Dinophyta, 2 Rodophyta, and 1 Cryptophyta. Except for Achnanthidium minutissimum - it being present in nearly all the sites - the species composition enabled the identification of 4 groups: (1) the Sierra-Morena rivers with a predominantly siliceous substrate and concomitantly low mineralized water $(<250 \mathrm{mg} / \mathrm{L})$; (2) the Doñana and lower-Guadiamar rivers of the lower-Guadalquivir with a high relative proportion of sodium; (3) rivers with any kind of disturbance, principally organic contamination, grouped regardless of their geographical location; (4) rivers of high calcium content that, though constituting a heterogeneous group, the majority of which belong to the Betic-Mountain region. According to our results, the subbasin was the one that determined the composition of the periphyton. The categorization of the rivers according to biota obtained in the present work differs from the hydrogeomorphological classification established by the Guadalquivir Hydrographic Confederation.
\end{abstract}

Key words: Achnanthidium minutissimum, benthic algae, ecoregions, Mediterranean rivers

\section{RESUMEN}

\section{Flora algal de la cuenca del río Guadalquivir. Su valor en la determinación de la ecorregionalización de la cuenca}

En cumplimiento con la Directiva Marco para las Políticas del Agua (DMA) de la Unión Europea fue necesario diagnosticar la calidad ecológica de los distintos tramos de los ríos de la cuenca del Guadalquivir. Para establecer una regionalización de las masas de agua agrupándolas en zonas de similares características se tomó en consideración la flora ficológica bentónica de la cuenca del río Guadalquivir y su valor en la ecorregionalización de la cuenca debido a que las algas bentónicas están entre los grupos de organismos que mejor definen la calidad del agua de los ríos. Se extrajeron muestras multihábitat en 109 tramos georeferenciados. Se identificaron 777 taxa algales: 397 Bacillariophyceae (diatomeas), 181 Chlorophyta, 148 Cyanoprokariota, 41 Euglenophyta, 4 Chrysophyceae, 3 Dinophyta, 2 Rodophyta y 1 Cryptophyta. Con excepción de Achnanthidium minutissimun, que estuvo presente en casi todos los sitios, según la composición algal pueden identificarse 4 grandes grupos: 1) Sierra Morena, con sustrato predominantemente siliceo y concomitantemente aguas poco mineralizadas $(<250 \mathrm{mg} / \mathrm{L}) ; 2)$ ríos de la depresión del Bajo Guadalquivir, Doñana y bajo Guadiamar con una proporción relativamente elevada de sodio; 3) ríos con algún tipo de perturbación, principalmente contaminación orgánica, agrupados independientemente de su situación geográfica, 4) ríos con alto contenido de calcio en sus aguas que, si bien forman un grupo heterogéneo, la mayoría pertenecen 
a la región de las Montañas Béticas. De acuerdo con nuestros resultados, la subcuenca fue la que determinó la composición del perifiton. La categorización de los ríos según la biota obtenida en el presente trabajo difiere de la clasificación hidrogeomorfológica establecida por la Confederación Hidrográfica del Guadalquivir.

Palabras clave: Achnanthidium minutissimun, algas bentónicas, ecorregiones, Ríos mediterráneos

\section{INTRODUCTION}

The objective of the Water Framework Directive (WFD) of the European Union is to insure that European aquatic ecosystems (i.e., rivers, lakes, wetlands, coastal waters) have a good ecologic status (European Union, 2000). Therefore, a diagnosis of the ecologic quality of the different reaches of the rivers became necessary along with the application of the appropriate measures in those that did not meet the requirements of the WFD for their restoration. At the present time, in areas affected by millennia of human intervention, a deduction of what degree of recovery would be required to restore an ecologic status close to the original conditions is highly problematical. Hence the need for a form of regionalization that can group the water masses into zones of similar biotic and abiotic characteristics. Once the individual features of each ecoregion are established, then the degree of alteration of a water body can be determined and quantified depending on the extent to which the concordance or discordance of the characteristics thus established coincides with those of the ecoregion in which that water body is located.

The overall biologic diversity of a given reach of a river is an emergent property of the associated ecosystem that mirrors the greater or lesser ecologic quality of that stretch. Water quality is one of the variables that influences the greater or lesser diversity of rivers, but not the only one. The spatial heterogeneity in each section-in terms of differences in water velocity, type of substrate, existence or absence of vegetation, among other features - determines the greater or lesser degree of species richness. The variations, both seasonal and annual, of the environmental conditions determine fluctuations in the resident populations; whose development depends on the temperature, light intensity, and hydrodynamic and physicochemical characteristics of the waters. The groups of organisms that best define the water quality of rivers - and without which a good ecologic status is impossible-are the benthic algae (Prygiel et al., 1999), the aquatic macrophytes (AFNOR, 2003), the macroinvertebrates (Alba-Tercedor et al., 2002), and the fish (European Union, 2000).

As to the benthic algae, certain extensive studies have been carried out in the large Iberian basins-e.g., Ebro (Oscoz et al., 2007), Duero (Blanco et al., 2008), and Guadiana (Urrea \& Sabater, 2009, 2012)-but most of those surveys took into account only the epilithic diatoms for the determination of biotic indices. Other studies also focused on diatoms in several Spanish rivers within the same region - such as Catalonia (Leira \& Sabater, 2005) or Baleares (Delgado et al., 2012) among others. Additional studies have referred to smaller basins, such as those of Ter River in Catalonia (Sabater et al., 1988; Ros et al., 2009). Information on diatoms in isolated rivers is also available, though data on other groups of benthic algae is much scarcer, having been generally carried out in small basins or isolated rivers such as those findings reported on the Cyanobacteria (Aboal, 1988; Douterello et al., 2004; Perona \& Mateo, 2006; Mateo et al., 2015). A particularly salient example is the extensive study of Rhodophyta in the rivers of Southeast Spain (Aboal, 1989), but little information on the Chlorophyta exists, except for that presented in the review by Cambra \& Aboal (1992). Far less frequent have been the studies carried out covering all groups of algae, and those reports that do exist refer to rivers from relatively small basins, such as the Segura (Aboal \& Llimona, 1984, 1989; Aboal, 1986, 1989, 1996). In contrast, no publications have covered the entire extent of a large basin in which the distribution of the algal groups in all the habitats has been analyzed.

The development of benthic algae is conditioned by hydrology as well as physicochemical and biotic factors (Biggs, 1996, 2000; Sabater et 
al., 1998; Hillebrand \& Sommer, 2000; Villeneuve et al., 2011). In the Iberian rivers the most relevant constituent features affecting the composition and abundance of benthic algae are the nutrients (mainly those containing $\mathrm{P}, \mathrm{N}$, and $\mathrm{Si}$ ) and the salinity (Aboal et al., 1996). Other influences such as the light, temperature, $\mathrm{pH}$, water velocity of the stream, and the nature of the substrate (e.g., siliceous or calcareous) can also cause variations in the development of the periphyton (Sabater, 2000; Leira \& Sabater, 2005; Leira et al., 2009). The water acidification can be significant in certain areas of Andalusia, especially in the channels of the Piritica Strip of the Sierra-Morena Mountains (Sabater, 2000; Toja et al., 2003; Martín et al., 2004).

Although the majority of the studies aimed at diagnosing water quality by means of benthic algae use exclusively diatoms (Hering et al., 2006; Torrisi et al., 2010), various investigations have clearly demonstrated that other groups of microalgae are also indicators. Several forms of measurement have been described (Hill et al., 2000; Griffith et al., 2002; Porter et al., 2008) and indices also devised considering only the composition of non-diatom, or so-called "soft", algae present (Gutowski et al., 2004; Schaumburg et al., 2004; Schneider \& Lindstrøm, 2011).

In the Guadalquivir-River basin, the Guadalquivir Hydrographic Confederation (Confederación Hidrográfica del Guadalquivir) has classified the river sections according to their hydrogeomorphology, following the guidelines of the Center of Public-Works Experimentation and Studies; (Centro de Estudios y Experimentación de Obras Públicas; CEDEX, 2004), as such discriminating 13 different classes, or typologies (Confederación Hidrográfica del Guadalquivir, 2004). The elements used in that classification comprise: the average annual flow, the slope and order of the river, the latitude and altitude, the base conductivity (a derivative of the lithology of the substrate), the average temperature, and the thermal amplitude. In this basin, in a previous publication, we have diagnosed the water quality of different stretches of the Guadalquivir by means of the Diatom Biotic Indices (Martín et al., 2010), but none of the benthic algae have been analyzed within the rubric of the WFD criteria.
Since benthic algae are known to be informative indicators of the ecologic status of rivers, this research - the first of its kind - constituting a survey of all the benthic algal groups found in the rivers of the Guadalquivir basin, was carried out with the objective of determining the nature of that algal flora and discovering whether or not, on the basis of that distribution, sectors or regions could be discriminated that were complementary to those established previously from the hydrogeomorphologic characteristics.

\section{MATERIAL AND METHODS}

\section{Study area}

The Guadalquivir-River basin —of $57527 \mathrm{~km}^{2}$ in total area, with a Mediterranean climate, and varying in altitude from a maximum of more than $3000 \mathrm{~m}$ down to an average of $150 \mathrm{~m}$ above sea level in the valley - can be divided into three large units that differ in their lithologic composition, structure, and predominant land uses; all of which features affect the characteristics of the rivers within (Fig. 1). (1) The Sierra-Morena mountains, to the North, contain the source of most of the tributaries of the right bank of the basin. That area is the most forested: there, the Mediterranean woods abound and, above all, the dehesa-i.e., the ancient grazing woodland, unique to Iberia. The rivers of this unit have sparsely mineralized water $(<250 \mathrm{mg} / 1$ of total salts) that is, in general, of good quality. The water of those rivers is classified as siliceous (Margalef et al., 1976; Armengol et al., 1991). (2) The Betic Mountains, to the South and East of the main channel, where all the tributaries of the left bank and some of the right bank are born, has a lower degree of forestation than that of the Sierra Morena along with a greater proportion of land devoted to agriculture, especially olive plantations. The rivers that arise in this unit oscillate in the average salt content between $250 \mathrm{mg} / \mathrm{l}$ and $1-2 \mathrm{~g} / \mathrm{l}$, and the water quality is quite variable (Martín et al., 2010). (3) The Guadalquivir-River valley - the location of the main channel-is an eminently agricultural area, with a predominance of olive plantations. Since the main channel receives the flow from the tributaries arising from 


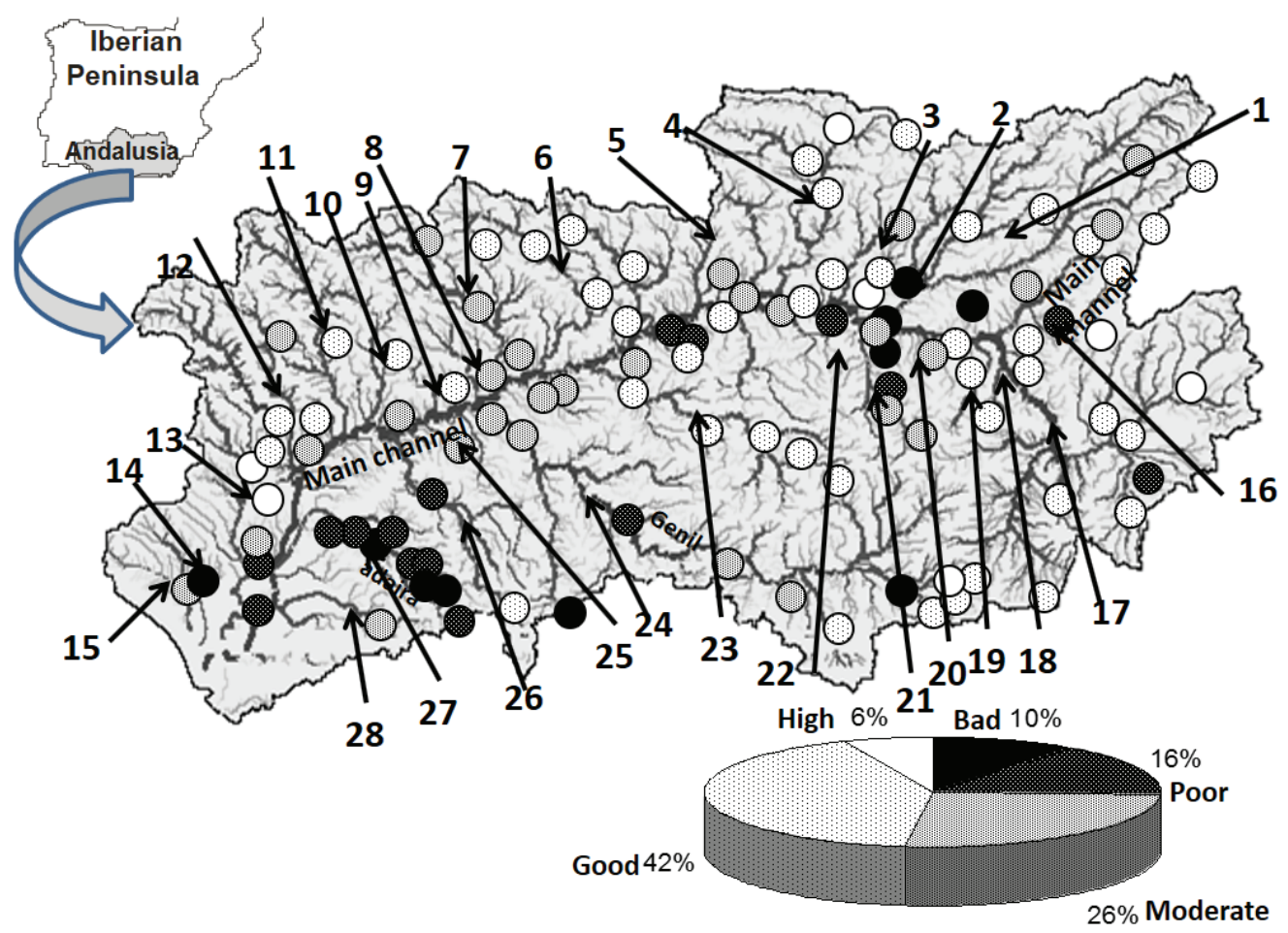

Figure 1. Location of the river stretches analyzed within the Guadalquivir-River basin. The quality of the river water is indicated according to the diatom pollution-sensitivity index as denoted in the pie diagram to the lower right. The location of the subbasins studied is specified, as well as their main channel: 1. Guadalimar, 2. Guadiel, 3. Rumblar, 4 Jándula, 5. Arenoso-Arenosillo, 6. Guadalmellato, 7. Guadiato, 8. Bembézar, 9. Retortillo, 10. Rivera de Huéznar, 11. Viar, 12. Rivera de Huelva, 13. Guadiamar, 14. Arroyo de El Partido, 15. Arroyo de La Rocina, 16. Río de la Vega, 17. Guadiana Menor, 18. Jandulilla, 19. Bédmar, 20. Torres, 21. Guadalbullón, 22. Guadatin, 23. Guadajoz, 24. Genil, 25. Arroyo Sta. María, 26. Corbones, 27. Guadaira, 28. Salado. The inset to the upper left depicts the geographical orientation of Andalusia within the Iberian Peninsula. Localización de los tramos de río estudiados en la cuenca del río Guadalquivir. Se indica la calidad de sus aguas obtenida por el índice de diatomeas IPS. Se señala la situación, además del cauce principal, de las subcuencas estudiadas: 1. Guadalimar, 2. Guadiel, 3. Rumblar, 4. Jándula, 5. Arenoso-Arenosillo, 6. Guadalmellato, 7. Guadiato, 8. Bembézar, 9. Retortillo, 10. Rivera de Huéznar, 11. Viar, 12. Rivera de Huelva, 13. Guadiamar, 14. Arroyo de El Partido, 15. Arroyo de La Rocina, 16. Río de la Vega, 17. Guadiana Menor, 18. Jandulilla, 19. Bédmar, 20. Torres, 21. Guadalbullón, 22. Guadatin, 23. Guadajoz, 24. Genil, 25. Arroyo Sta. María, 26. Corbones, 27. Guadaira, 28. Salado. El recuadro superior izquierdo representa la orientación geográfica de Andalucía dentro de la Península Ibérica.

both banks, the salt content is intermediate between those of the other zones.

\section{Algal sampling}

The 109 reaches of sampled rivers corresponded to 95 sites of the Integrated-Water-Quality Network (Red Integrada de Calidad de Agua, ICA), while 14 sites located in the reference sections were determined by CEDEX. The physicochemical data were provided by those respective institutions. The sampling-performed during only one season (spring) of the year to avoid the effect of the seasonal variations and the lower flow in the summer - was done for two consecutive years, 2004 and 2005, because of the short period of time that the streams and rivers flow during spring season in Andalusia.

At each sampling site, we analyzed a reach of 100-m minimal extension, covering units of rapids and backwaters in those courses when present. In order to collect a composite sample representative of a given reach, we followed the procedures for the sampling of multihabitat algae 
stated in the protocols of the USA's Environmental Protection Agency (EPA; Stevenson \& Bahls, 1999) and visually estimated the percent coverage of each type of substrate available for colonization along with the ambient conditions at that location. The sampling scraped off the surface of each substrate was done in proportion to the coverage of that substrate with the total surface of each section.

We tried to take samples covering the different textures, abundances, and colors of the periphyton present (Aloi, 1990). If the rocks could not be extracted from the water, various suction elements (e.g., syringe, pipette) aided the brushing used for removal. In the absence of natural rocks, we took samplings from artificial hard supports (e.g., civil work substrates) and collected the thallus of macroalgae. For sampling helophytes (e.g., Typha sp. or Phragmites australis), four or five portions were taken from about $5 \mathrm{~cm}$ below the water surface to about $5 \mathrm{~cm}$ above the sediment.

In the laboratory, the algae were removed by gently scraping the stems and leaves with a coverslip. The limnophytes (e.g., Rannunculus sp. or Myriophyllum sp.) of delicate and very finely divided leaves were introduced into a jar with tap water and then vigorously agitated until the epiphytic algae became detached. In this manner, an overall sample was obtained, consisting in the entire collection, in a single bottle, of the algae removed from all the existing substrates within a given river reach. This procedure was performed twice more, to obtain a total of three replicates that were finally fixed with $4 \%(\mathrm{v} / \mathrm{v})$ aqueous formalin.

\section{Identification of taxa}

The identification of the species was performed under a Nikon E-200 light microscope with maximum magnification of 1000X. A 10-ml aliquot was used for analysis of the diatom samples that we treated to remove organic matter using the method of hydrogen peroxide in the heat, followed by the addition of $\mathrm{HCl}$, to remove carbonates. The treatments as well as the permanent preparations mounted on Naphrax ${ }^{\mathrm{TM}}$ were carried out following the European Committee for Standarization's protocol EN 13946 (2003). Those samples in which the species could be easily confused with others were analyzed by scanning electron microscopy following the recommendations of Lobo et al. (1990) and Morales et al. (2001). Aliquots of material were mounted on glass pads and metallized with gold-palladium for the microscopical analyses. These observations were made with a MEB Jeol J.S.M. 6360 LV instrument installed at the Servicio de Microscopía Electrónica de la Facultad de Ciencias Naturales y Museo, UNLP (La Plata, Argentina).

The list of monographs and other studies used for algal identifications is available at http://www. limnetica.net/en/limnetica ( $c f$. Appendix S1).

\section{Statistical analysis}

For the discrimination of biotic ecoregions, we used the presence-versus-absence data of all the algae found in the multihabitat samples of the 109 reaches surveyed. Nonparametric multidimensional-scaling (MDS) analyses were used followed by the application of the analysis of similarities (ANOSIM) test to check the strength of the groups by means of the statistical package PRIMER, 5.0.

\section{RESULTS}

During this study we identified 777 taxa, and down to the species level in most instances; while in certain groups we could determine even the subspecies or forms, though in others- such as the adnate Chlorophyta - only the genus, owing to the lack of reproductive structures. Bacillariophyceae (diatoms) was the most diverse group with 397 taxa, followed by Chlorophyta (at 181 taxa) and Cyanophyta or Cyanoprokariota (at 148 taxa). Numerous Euglenophyta (at 41 taxa) were also identified, whereas from other groups only few taxa were found-i.e., 2 Rhodophyta, 3 Dinophyta, 1 Cryptophyta, and 4 Chrysophyceae. Table S1 (available at http://www. limnetica.net/en/limnetica) contains a complete listing of these taxa and their presence or absence in the different subbasins.

According to the order of the MDS analysis, the reaches were structured into 4 large river groups (Fig. 2) that can be considered within 
distinct ecoregions according to each biotic classification. These 4 groups are: (1) rivers of the Sierra Morena, with a predominantly siliceous substrate; (2) rivers of the depression of the lower Guadalquivir basin and the Doñana National Park plus the lower Guadiamar River, with water containing a relatively high concentration of sodium; (3) rivers with some kind of intense disturbance, mainly organic pollution; and (4) a much more heterogeneous group encompassing the basins of the rivers Genil, Guadajoz, Guadalbullón, Guadiana Menor, Guadalimar and the upper and middle courses of the Guadalquivir that, in general, are located on predominantly calcareous substrates. The ANOSIM test indicated that these 4 groups are significantly different $(\mathrm{R}=0.613, p<0.01)$.

Group 1 contains the Sierra-Morena rivers, on a substrate of shales, schist, and granite. Although the most abundant cation is calcium, its concentration is nevertheless very low (Guzmán Alvarez, 2004). This group comprises 37 reaches in which 530 species have been identified, with 16 appearing in more than $50 \%$ of the sections and the most frequent-Achnanthidium minutissimum, Amphora

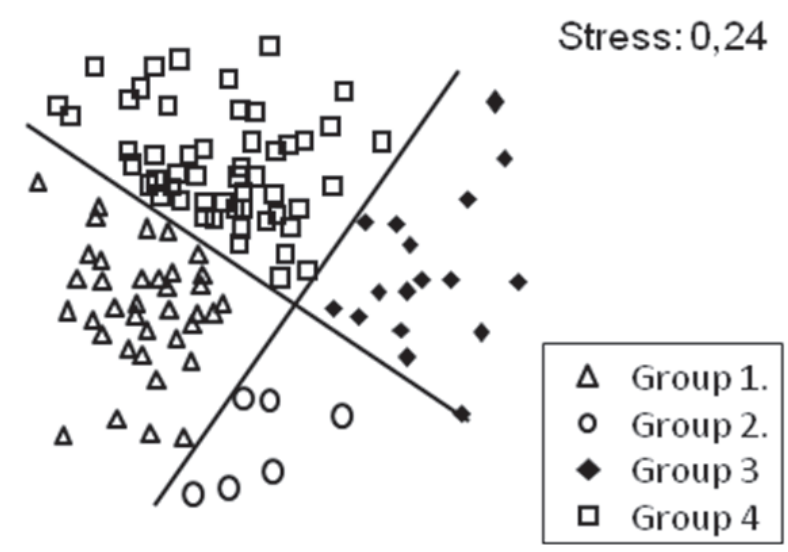

Figure 2. Distribution of the sampling points according to the MDS analysis carried out with the data on the presence or absence of the algae identified. $C f$. the text for the description of each group. Key to the symbols: triangles, Group 1; circles, Group 2; diamonds, Group 3; squares, Group 4. Distribución de los puntos de muestreo según el análisis MDS realizado con los datos de presencia/ausencia de las algas identificadas. En el texto se encuentra la descripción de los grupos. Clave para los símbolos: triángulos, Grupo 1; círculos, grupo 2; Diamantes, Grupo 3; cuadrados, Grupo 4. pediculus, Gomphonema parvulum, Ulnaria ulna, and Scenedesmus aff. acutus-being present in more than $70 \%$. Group 2 consists of 7 reaches located in the lower Guadalquivir. In this water sodium is usually relatively abundant, though that ion is not necessarily the dominant cation. In this group, 252 species were identified. Of this number, 19 were present in more than $50 \%$ of the sections; with Pseudoanabaena limnetica, Pseudoanabaena catenata, Nitzschia palea, and Monoraphidium contortum being the most frequent (occurring in more than $80 \%$ of the sections). Group 3 contains 17 reaches belonging to rivers of very different areas - such as the Guadaira, Guadiel, Guadalimar, Genil, and lower Guadiana-as well as the main channel of the Guadalquivir. The most frequent species (in more than $70 \%$ of the reaches) were Navicula veneta, Nitzschia capitellata, Nitzschia frustulum, Tryblionella hungarica, and Euglena variabilis. Group 4 combines the rest of the reaches (52 in total), most of which stretches belong to the rivers of the Betic Mountains. Although this group is more heterogeneous, the main common characteristic of the constituent rivers is the high calcium content of the water. In these stretches, 460 species were identified, of which 17 appeared in more than $50 \%$ of the reaches. The most frequent in those sections were $A$. pediculus, A. minutissimum, Achnanthidium saprophilum, Cocconeis placentula var. euglypta, Rhoicosphenia abbreviata, and Navicula tripunctata. A. minutissimum was the most frequent species throughout the entire basin; having been recorded in $95 \%$ of the reaches of the Sierra Morena rivers, in $71 \%$ of those of the lower Guadalquivir, in $82 \%$ of the rest of the only moderately polluted sections, and even in $31 \%$ of the highly contaminated stretches.

To more completely understand the influence of natural hydrogeomorphologic conditions on benthic algae, we carried out an ANOSIM analysis excluding the highly contaminated sections, which test revealed that the differences between the ecoregions defined through the spectra of periphyton present are somewhat weaker $(\mathrm{R}=$ $0.550, p=0.001)$ than those of the previous ANOSIM, though nevertheless significant.

In view of the large number of taxa having a low frequency of occurrence (i.e., being present in 
$<10 \%$ of the sites) and the scanty relevant information offered by the extremely frequent taxa (i.e., being present in $>50 \%$ ), one might suppose that, by using only the presence-versus-absence data, those taxa could distort the results. For this reason, we repeated the MDS and ANOSIM analyses for all the sections, but with the inclusion of only those taxa present between $10 \%$ and $50 \%$ of the reaches. The results of those selective analyses indicated that, in general, the taxa with intermediate frequencies exhibited significant differences between the subbasins, as had been seen with the analysis of the total taxa, but the $\mathrm{R}$ was lower $(\mathrm{R}=0.41)$ than the previous value.

\section{DISCUSSION}

A priori we expected that the river stretches would be ordered according to the 13 different types defined by the WFD (hydrogeomorphological classification). Nevertheless, according to our results, the subbasin, the smallest-scale unit, was the one that determined the composition of the periphyton. Therefore, the categorization of the rivers according to biota obtained in the present work proved not to be similar to that established by the original hydrogeomorphological classification of WFD. Previous studies from Spain (Munné \& Prat, 2004; Tornés, 2009) have discussed whether the typologies described by the WFD are truly applicable to biota and another study (Hawkings et al., 2000) also determined classifications based on biologic findings. The discrepancy between the classification given by the physical geographic features and that based on biologic data has been the focus of the controversy among specialists (Hawkins \& Norris 2000). In the present work, the result of the a-posteriori approach involving all the algal groups also differed from the a-priori classification. The repetition of the analysis without the disturbed sites-and especially the MDS and ANOSIM results with the species of intermediate prevalence-reinforced this discrepancy.

High levels of contamination facilitate an association of species that colonize a given reach regardless of other characteristics of its geographical location. Since the nature of the benthic algae involves the abiotic effects of water chemistry and the physical and geomorphologic characteristics of a given water body, those algae have been considered a good indicator of anthropically polluted water. Tornés (2009) concluded that physiographic differences were only evident in undisturbed sites, whereas nutrient enrichment and other human disturbances could mask the regional differences in the distribution of diatom communities. Therefore, not only physical conditions but also the ionic composition of water linked to human influence are both relevant and essential in classifying water bodies (Potapova \& Charles, 2002). The other, nonpolluted ecoregions are accordingly differentiated basically by the effect of the variations in lithology of their basins, which feature is reflected in the concentration and proportion of the principal di- and trivalent cations (Junta de Andalucía, 2004; Vera, 2004). Although, in general, the entire Guadalquivir basin is to some extent affected by human activities; nevertheless, if the disturbance is not especially severe, the effect of the regionally specific di- and trivalent cations can become manifest. In contrast, the reaches within the fertile plain of the Guadalquivir and the Genil rivers contain a high proportion of silt, and laminar flow predominates. According to Wagenhoff et al. (2011), the presence of fine sediment can become a determinant condition for the distribution of phytobenthic algae in rivers.

Because A. minutissimum is ubiquitous and is the most prevalent species throughout the entire area surveyed, the presence of that species is inconsistent with the proposed ecologic- versus anthropic-impact-based regionalization of the species registered. This occurrence per se of this species is difficult to interpret because $A$. minutissimum is a pioneer - a highly tolerant species that appears both in clean water of highest sections and in water bodies that have undergone a physical or chemical disturbance, as in temporary streams or in areas affected by metals or pesticides (for example, $c f$. Martín \& Fernández, 2012).

The analysis carried out considering only the taxa of intermediate frequency of appearance indicated that those taxa - in contrast to A. minutissimum - detected less significant differences than those obtained with all the periphyton. These taxa of intermediate prevalence can play an indis- 
putable role in the quality-associated segregation of water bodies. As many poorly represented taxa are exclusive to a reach, a subbasin, or an ecoregion, we recommend an increase in the effort to ascertain the taxa exclusive to each subbasin, in order to more clearly define the reference conditions and their variability, whatever the classification system used might be.

In conclusion, despite the virtues of the acquisition of quantitative results, we still would emphasize that qualitative multihabitat analyses per se provide valuable information to perform the typification required in the management of aquatic ecosystems, since those data offer the possibility of characterizing and expanding the analyses of the different floras and their distribution. Therefore, in agreement with Stevenson \& Smol (2003), we recommend the use of qualitative data in areas of large basins with high geographical variability. This recommendation is furthermore consistent with what we have deduced from the results of the present work - namely, that the extra information obtained through the analysis of quantitative samples offers no advantage over a presence-versus-absence determination in comprehensive multihabitat samplings. In addition, the generation of extensive databases that relate the presence or absence of taxa in relation to environmental variables would contribute to the knowledge of the niche limitations from which the indicator value of specific organisms could be established, and accurate biotic indices designed.

\section{ACKNOWLEDGEMENTS}

This research was funded by the Guadalquivir Hydrographic Confederation. We thank the two anonymous reviewers for the constructive suggestions that allowed us to improve the manuscript. Dr. Donald F. Haggerty, a retired academic career investigator and native English speaker, edited the final version of the manuscript.

\section{REFERENCES}

AFNOR. 2003. Qualité de l'eau: determination de l'indice biologique macrophytique en rivière (IBMR) - NFT 90-395.

ABOAL, M \& X. LLIMONA. 1984. Aportación al conocimiento de la flora del río Mula, Murcia S.E. de España. Limnetica, 1: 141-147. ABOAL, M. 1986. Flora algal de la rambla del Tinajón (Río Segura), Murcia, S.E. España. Limnetica, 2: 103-108.

ABOAL, M. 1988. Aportación al conocimiento de las algas epicontinentales del sudeste de España. III: Cianofíceas (Cyanophyceae Schaffner 1909). Anales Jardín Botánico de Madrid, 45 (1): 3-46.

ABOAL, M. 1989. Contribución al conocimiento de las algas epicontinentales del SE de España II: Los rodófitos (Rhodophyceae). Lazaron, 11: 115-122.

ABOAL M. y X. LLIMONA. 1989. Los poblamientos algales bentónicos del Río Segura y su relación con la calidad del agua. Candollea, 44 (1): 199- 208.

ABOAL, M., M.A. PUIG \& G. SOLER. 1996. Diatom assemblages in some Mediterranean temporary streams in southeastern Spain. Archiv für Hydrobiologie, 136 (4): 509-527.

ALBA-TERCEDOR, J., P. JÁIMEZ-CUÉLLAR, M. ÁLVAREZ, J. AVILÉS, N. BONADA, J. CASAS, A. MELLADO, M. ORTEGA, I. PARDO, N. PRAT, M. RIERADEVALL, S. ROBLES, C.E. SÁINZ-CANTERO, A. SÁNCHEZ-ORTEGA, M.L. SUÁREZ, M. TORO, M.R. VIDAL-ABARCA, S. VIVAS \& C. ZAMORA-MUÑOZ. 2002. Caracterización del estado ecológico de ríos mediterráneos ibéricos mediante el índice IBMWP (antes BMWP'). Limnetica, 21 (3-4): 175-185.

ALOI, J. E. 1990. A critical review of recent freshwater periphyton field methods. Canadian Journal of Fisheries and Aquatic Sciences, 47(3): 656-670. DOI: 10.1139/f90-073

ARMENGOL, J., J.L. RIERA \& J.A. MORGUÍ. 1991. Major ionic composition in the spanish reservoirs. Verhandlungen des Internationalen Verein Limnologie, 24 (2): 1363-1366. DOI: 10.1080/03680770.1989.11898982

BIGGS, B. J. 1996. Hydraulic disturbance as a determinant of periphyton development in stream ecosystems. Ph.D. Thesis. University of Canterbury, Christchurch, New Zealand.

BIGGS, B. J. 2000. Eutrophication of streams and rivers: dissolved nutrient-chlorophyll relationships for benthic algae. Journal of the 
North American Benthological Society, 19 (1): 17-31. DOI: $10.2307 / 1468279$

BLANCO, S., L. ECTOR, V. HUCK, O. MONNIER, H.M. CAUCHIE, L. HOFFMAN, E. BÉCARES. 2008. Diatom assemblages and water quality assessment in the Duero basin (Spain). Belgian Journal of Botany, 141(1): 137.

CAMBRA, J. \& M. ABOAL. 1992. Filamentous green algae of Spain: distribution and ecology. Limnetica, 8: 213-220.

CEDEX. 2004. Caracterización de los tipos de ríos y lagos. Versión 1.0. Madrid, Spain. Available in: http://eflus.com/index.php?option=com docman \&task $=$ doc view\&gid $=196 \&$ Itemid $=109$

CONFEDERACIÓN HIDROGRÁFICA DEL GUADALQUIVIR. 2004. Caracterización de la demarcación de Aguas superficiales. Informe Resumen de los artículos 5 y 6 de la Directiva Marco del Agua. Ministerio de Medio Ambiente. Available in: http://www.chguadalquivir.es/ export/sites/default/portalchg/planHidrologico Demarcacion/directivaMarcoDelAgua/ ficheros/04_SWB_1_TIPOLOGIA_MASAS SUPERFICIALES.p.pdf

DELGADO, C., I. PARDO \& L. GARCÍA. 2012. Diatom communities as indicators of ecological status in Mediterranean temporary streams (Balearic Islands, Spain). Ecological indicators, 15 (1): 131-139. DOI: 10.1016/j.ecolind. 2011.09 .037

DOUTERELLO, I., E. PERONA \& P. MATEO. 2004. Use of cyanobacteria to assess water quality in running waters. Environmental pollution, 127(3): 337-384. DOI: 10.1016/ j.envpol.2003.08.016

EUROPEAN STANDARD EN 13946. 2003. Water quality - Guidance standard for the routine sampling and pretreatment of benthic diatoms from rivers. $14 \mathrm{pp}$. European Committee for Standarization, Brussels. Belgique.

EUROPEAN UNION. 2000. 2000/60/EC Directive of the European Parliament and the Council of 23 October establishing a framework for Community action in the field of water policy. OJ, L 327 (22.12.2000), 1-72. Water Framework Directive (WFD).

GRIFFITH, M. B., B. H. HILL, A.T. HERLIHY \& P.R. KAUFMANN. 2002. Multivariate analysis of periphyton assemblages in relation to environmental gradients in Colorado Rocky Mountain streams 1. Journal of Phycology, 38(1): 83-95.

GUTOWSKI, A., J. FOERSTER \& J. SCHAUMBURG. 2004. The use of benthic algae, excluding diatoms and Charales, for the assessment of the ecological status of running fresh waters: a case history from Germany. Oceanological and Hydrobiological Studies, 2: 3-15.

GUZMÁN ÁLVAREZ, J. R. 2004. Geografia de los paisajes del olivar andaluz. Consejería de Agricultura y Pesca, Junta de Andalucía, Sevilla.

HAWKINS, C. P. \& R.H. NORRIS. 2000. Performance of different landscape classifications for aquatic bioassessments: introduction to the series. Journal of the North American Benthological Society, 19: 367-369.

HAWKINS, C. P., R. H. NORRIS, J. N. HOGUE, \& J. W. FEMINELLA. 2000. Development and evaluation of predictive models for measuring the biological integrity of streams. Ecological Applications, 10 (5): 1456-1477. DOI: 10.1890/1051-0761(2000)010\%5B1456: DAEOPM\%5D2.0.CO;2

HERING, D., R. K. JOHNSON, S. KRAMM, S. SCHMUTZ, K. SZOSZKIEWICZ \& P. F. VERDONSCHOT. 2006. Assessment of European streams with diatoms, macrophytes, macroinvertebrates and fish: a comparative metric-based analysis of organism response to stress. Freshwater Biology, 51 (9): 1757-1785. DOI: $10.1111 /$ j.1365-2427.2006.01610.x

HILL, B. H., A. T. HERLIHY, P. R. KAUFMANN, R. J. STEVENSON, F. H. MCCORMICK\& C. B. JOHNSON. 2000. Use of periphyton assemblage data as an index of biotic integrity. Journal of the North American Benthological Society, 19 (1): 50-67. DOI: $10.2307 / 1468281$

HILLEBRAND, H. \& U. SOMMER. 2000. Diversity of benthic microalgae in response to colonization time and eutrophication. Aquatic Botany, 67 (3): 221-236. DOI: 10.1016/S03043770(00)00088-7

JUNTA DE ANDALUCÍA. 2004. Conjunto de Datos de Geodiversidad de Andalucia: Geología, Edafología, Geomorfología y 
Georrecursos. Consejería de Medio Ambiente. Sevilla, Spain.

LEIRA, M., \& S. SABATER. 2005. Diatom assemblages distribution in catalan rivers, NE Spain, in relation to chemical and physiographical factors. Water Research, 39 (1): 73-82. DOI: 10.1016/j.watres.2004.08.034

LEIRA, M., G. CHEN, C. DALTON, K. IRVINE \& D. TAYLOR. 2009. Patterns in freshwater diatom taxonomic distinctness along an eutrophication gradient. Freshwater Biology, 54 (1): 1-14. DOI: 10.1111/j.1365-2427.2008. 02086.x

LOBO, E.A., S. KITAZAWA \& H. KOBAYASI. 1990. The use of scanning electron microscopy as a necessary complement of light microscopy diatom examination for ecological studies. Diatom, 5: 33-43.

MARGALEF, R., PLANAS, D., ARMENGOL, J., VIDAL, A., PRAT, N., GUISET, A., J., TOJA \& M. ESTRADA. 1976. Limnología de los embalses españoles. D.G. Obras Hidráulicas. M.O.P., Madrid, Spain.

MARTÍN, G., E. ALCALÁ, C. SOLÁ, A. PLAZUELO, M. D. BURGOS, E. REYES \& J. TOJA. 2004. Efecto de la contaminación minera sobre el perifiton del río Guadiamar. Limnetica, 23: 315-330.

MARTÍN, G., J. TOJA, S.E. SALA, R. FERNÁNDEZ, I. REYES, M.A. CASCO. 2010. Application of diatom biotic indices in the Guadalquivir river basin, a Mediterranean basin. Which one is the most appropriated? Environmental Monitoring and Assessment, 170 (1-4): 519-534. DOI: $10.1007 / \mathrm{s} 10661-009-1254-5$

MARTÍN, G. \& M.R. FERNÁNDEZ. 2012. Diatoms as Indicators of Water Quality and Ecological Status: Sampling, Analysis and Some Ecological Remarks, In Ecological Water Quality - Water Treatment and Reuse, Dr. Voudouris (Ed.), ISBN: 978-953-51-0508-4, InTech. DOI: $10.5772 / 33831$

MATEO, P., F. LEGANES, E. PERONA \& F. FERNANDEZ-PIÑAS. 2015. Cyanobacterias as bioindicators. Biodiversity Consevation, 24 (4): 909- 948.

MORALES, E. A., P. A. SIVER, \& F. R. TRAINOR. 2001. Identification of diatoms (Bacillariophyceae) during ecological assessments: comparison between light microscopy and scanning electron microscopy techniques. Proceedings of the Academy of Natural Sciences of Philadelphia, 151 (1): 95-103. DOI: 10.1635/0097-3157(2001)151\%5B0095: IODBDE\%5D2.0.CO;2

MUNNÉ, A. \& N. PRAT. 2004. Defining river types in a Mediterranean area: a methodology for the implementation of the EU Water Framework Directive. Environmental management, 34 (5): 711-729. DOI: 10.1007/s00267-003-0098-y OSCOZ, J. J. GOMÁ, L. ECTOR, J. CAMBRA, M. PARDOS \& C. DURÁN. 2007. Estudio comparativo del estado ecológico de los ríos de la cuenca del Ebro mediante macroinvertebrados y diatomeas. Limnetica, 26 (1): 143-158.

PERONA, E. \& P. MATEO. 2006. Benthic cyanobacterial assemblages as indicators of nutrient enrichment regimes in a Spanish river. Acta hydrochimica et hydrobiologica, 34 (1-2): 67-72. DOI: 10.1002/aheh.200500611

PORTER, S. D., D. K. MUELLER, N. E. SPAHR, M. D. MUNN \& N. M. DUBROVSKY. 2008. Efficacy of algal metrics for assessing nutrient and organic enrichment in flowing waters. Freshwater Biology, 53 (5): 1036-1054. DOI: 10.1111/j. 1365-2427.2007.01951.x

POTAPOVA, M. G. \& D. F. CHARLES. 2002. Benthic diatoms in USA rivers: distributions along spatial and environmental gradients. Journal of Biogeography, 29 (2): 167-187. DOI: $10.1046 /$ j.1365-2699.2002.00668.x

PRYGIEL, J., M. COSTE \& J. BUKOWSKA. 1999. Review of the major diatom-based techniques for the quality assessment of rivers - State of the art in Europe. In Use of algae for monitoring rivers III: Prygiel, J., B. A. Whitton \& J. Bukowska (eds.): 224-238. Agence de L'Eau Artois-Picardie. Douai, France, 271 pp. ROS, M. D., J. P. MARÍN-MURCIA \& M. ABOAL. 2009. Biodiversity of diatom assemblages in a Mediterranean semiarid stream: implications for conservation. Marine and Freshwater Research, 60 (1): 14-24. DOI: 10.1071/MF07231

SABATER, S., F. SABATER \& J. ARMENGOL. 1988. Relationships between diatom assem- 
blages and physico-chemical variables in the river Ter (NE Spain). Hydrobiologia, 73 (2): 171-179. DOI: 10.1002/iroh.19880730204

SABATER, S. 2000. Diatom communities as indicators of environmental stress in the Guadiamar river, S-W. Spain, following a major mine tailings spill. Journal of Applied Phycology, 12: 113-124.

SCHAUMBURG, J., C. SCHRANZ, J. FOERSTER, A. GUTOWSKI, G. HOFMANN, P. MEILINGER \& U. SCHMEDTJE. 2004. Ecological classification of macrophytes and phytobenthos for rivers in Germany according to the Water Framework Directive. Limnologica- Ecology and Management of Inland Waters, 34 (4): 283-301. DOI: 10.1016/S00759511(04)80002-1

SCHNEIDER, S. \& E. A. LINDSTRØM. 2011. The periphyton index of trophic status PIT: a new eutrophication metric based on non-diatomaceous benthic algae in Nordic rivers. Hydrobiologia, 665(1): 143-155. DOI: 10.1007/s10750-011-0614-7

STEVENSON, R. J. \& L.L. BAHLS. 1999. Periphyton protocols. In Rapid Bioassessment Protocols for Use in Streams and Wadeable Rivers: Periphyton, Benthic Macroinvertebrates and Fish. Barbour, M.T., J. Gerritsen, B.D. Snyder \& J.B. Stribling (eds.). Chapter 6. EPA 841-B-99-002. U.S. Environmental Protection Agency; Office of Water, Washington, D.C. USA. Second Edition.

STEVENSON, R. J. \& J. P. SMOL. 2003. Use of algae in environmental assessments. In: Freshwater Algae of North America: Ecology and Classification: 775-804. Elsevier. Michigan State University. USA. DOI: 10.1016/B978-012741550-5/50024-6

TOJA, J., E. ALCALÁ, G. MARTÍN, C. SOLÀ, M. PLANS, M. BURGOS, A. PLAZUELO \& N. PRAT. 2003. Evaluación del efecto del vertido tóxico sobre la calidad del agua y los sedimentos de los ríos Agrio y Guadiamar. Ciencia y Restauración del río Guadiamar, Consejería de Medio Ambiente, Sevilla, Spain: 78-92.

TORNÉS, E. 2009. Distributional patterns of diatom communities in Mediterranean rivers. PhD Thesis. University of Girona, Spain: $154 \mathrm{pp}$.

TORRISI, M., S. SCURI, A. DELL'UOMO \& M. COCCHIONI. 2010. Comparative monitoring by means of diatoms, macroinvertebrates and chemical parameters of an Apennine watercourse of central Italy: The river Tenna. Ecological Indicators, 10 (4): 910-913. DOI: 10.1016/j.ecolind 2010.01 .010

URREA, G. \& S. SABATER. 2009. Epilithic diatom assemblages and their relationship characteristics in an agricultural watershed (Guadiana river, SW Spain). Ecological indicators, 9 (4): 693-703.

URREA, G. \& S. SABATER. 2012. Identifying reference benthic diatom communities in an agricultural watershed (Guadiana River, SW Spain). Hydrobiologia, 695 (1): 171-184

VERA, J. A. 2004. Proyecto Andalucía: Geología I. Serie Naturaleza. Tomo XXVI. SGE-IGME, Madrid. Spain.

VILLENEUVE, A., B. MONTUELLE \& A. BOUCHEZ. 2011. Effects of flow regime and pesticides on periphytic communities: evolution and role of biodiversity. Aquatic toxicology, 102(3): 123-133. DOI: 10.1016/j.aquatox. 2011.01 .004

WAGENHOFF, A., C. R. TOWNSEND, N. PHILLIPS \& C. D. MATTHAEI. 2011. Subsidy-stress and multiple-stressor effects along gradients of deposited fine sediment and dissolved nutrients in a regional set of streams and rivers. Freshwater Biology, 56 (9): 1916-1936. DOI: 10.1111/j.1365-2427.2011. 02619.x 